\section{Apple Tree and Fruit Responses to Early Termination of Irrigation in a Semi-arid Environment}

\author{
Robert C. Ebel ${ }^{1}$ \\ Department of Horticulture, Auburn University, Auburn, AL 36849
}

\author{
Edward L. Proebsting ${ }^{2}$ and Robert G. Evans ${ }^{3}$ \\ Irrigated Agriculture Research and Extension Center, 24106 N. Bunn Road, \\ Prosser, WA 99350
}

Additional index words. Malus $\times$ domestica, total available soil water, stem water potential, leaf conductance

\begin{abstract}
Drought stress was imposed in two 'Delicious' apple (Malus $\times$ domestica Borkh.) orchards on a sandy loam soil of different soil depths $(0.8$ and $1.2 \mathrm{~m})$ in the semi-arid environment of central Washington by withholding irrigation all season or from 3, 5, 7, 9, $11,13,15$, or 17 weeks before harvest. Total pan evaporation was $1005 \mathrm{~mm}$ and precipitation was negligible from May through Sept. Soil of the control trees was near field capacity all season, and stem water potential $\left(\Psi_{\text {stem }}\right)$ averaged $-1.29 \mathrm{MPa}$. Total available soil water (TAW) declined after irrigation was terminated for each treatment. As TAW declined to $35 \%$, the TAW that commercial growers are recommended to allow soil to dry to before irrigating, $\Psi_{\text {stem }}$ was $93 \%$ of the controls, fruit growth rate was $97 \%$ of the controls, and leaf senescence did not exceed the control trees. As TAW decreased below $30 \%$, leaves senesced acropetally starting with transition leaves near the bud-scale scar. Soil moisture of nonirrigated trees was depleted in July in the orchard on shallow soil and in late August in the orchard on deep soil. Normal June drop was reduced in the driest treatments, but crop load was not affected in the other treatments. There was no difference in drought response between the two rootstocks studied (M.7 and MM.111), but nonspurtype trees exhibited slightly greater symptoms of drought stress than the smaller spur-type trees. A Crop Water Deficit Index (CWDI) based on $\Psi_{\text {stem }}$ measurements was linearly related to fruit weight at harvest $\left(r^{2}=0.87\right)$. All trees were well-watered the following year and yield was reduced only for trees that were severely stressed the previous year.
\end{abstract}

The apple industry in the Pacific Northwest is located in a semi-arid environment where natural precipitation is not sufficient for fruit production. To meet the needs of the industry, water from melting snow in the Cascade mountains is stored in reservoirs and released to streams and irrigation canals to orchards during the growing season. Water is also used for generating hydroelectric power, to maintain viable salmon populations, and for human consumption. In some years, the snowpack is low and water supplies are not sufficient to meet demand, and the frequency and intensity of water shortages will likely increase as the population grows. Water shortages are of most concern in irrigation districts that have low water rights since water to irrigation canals is terminated early, sometimes before harvest.

There has been considerable research conducted on apple tree response to drought stress (Jones, et al., 1985; Landsberg and Jones, 1981). While all studies add to the understanding of apple response to drought stress in general, much of it is not directly applicable to late-

\footnotetext{
Received for publication 27 July 2000 . Accepted for publication 19 Mar. 2001

${ }^{1}$ Assistant Professor. To whom requests for reprints should be addressed. E-mail address; rcebel@ acesag.auburn.edu

${ }^{2}$ Professor Emeritus

${ }^{3}$ Agricultural Engineer.
}

season drought stress that might be experienced in the semi-arid environment of the Pacific Northwest. For example, many studies have been conducted in more humid climates, which usually have intermittant precipitation and more variable evaporative demand than semi-arid environments (Assaf et al., 1975; Ferree and Schmid, 1990; Higgs and Jones, 1991; Jones et al., 1985; Li et al., 1989; Naor et al., 1995; Powell, 1976). Much research has studied the feasibility of manipulating plant water deficits early in the season, which shifts growth from vegetative to reproductive organs and thus improves productivity while reducing pruning costs (Chalmers et. al. 1986; Chalmers et al., 1981; Ebel et al., 1993; Ebel et al., 1995; Mills, et al., 1997; Mitchell and Chalmers, 1982; Mitchell et al., 1986; Mitchell et al., 1984). In the event of early termination of irrigation in a semi-arid climate, however, drought stress will be imposed late in the season, during the cell enlargement stage of fruit growth. Many drought-stress studies have been conducted on potted trees, which provide little useful information for field-grown trees because of differences in drought response. Field-grown trees typically have larger soil water reservoirs per unit canopy area compared with potted trees, which slows development of drought symptoms. Apple trees become more drought resistant as the growing season progresses (Davies and Lakso, 1979).
Threats of water shortages in the Pacific Northwest have stimulated research on the response of tree-fruit crops other than apple to late-season drought, and cultural practices that can be implemented to mitigate damage (Proebsting and Middleton, 1980; Proebsting et al., 1981). The response of apple trees and fruit must be known so that management practices can be shifted to optimize productivity. The following study was conducted to evaluate the effects of early termination of irrigation on apple-tree productivity in the semi-arid climate of central Washington. The results are discussed with respect to the possibility of developing models that could be used to predict the impact of late-season drought stress on productivity at harvest. Such an advance-warning system would allow growers more time to adjust cultural practices to either preserve the current crop or, in the case of a severe water shortage, preserve the trees for long-term productivity.

\section{Materials and Methods}

Experimental sites. The experiment was conducted on the Roza irrigation district in the lower Yakima valley near Prosser, Wash. (lat. $45^{\circ} \mathrm{N}$; long. $119^{\circ} \mathrm{W}$ and $380 \mathrm{~m}$ above sea level). Average annual precipitation (192476) is $190 \mathrm{~mm}$, of which $\approx 50 \mathrm{~mm}$ falls during the May through September growing season (Kleingartner, 1977). An agricultural weather station was located within $350 \mathrm{~m}$ of the experimental orchards.

This experiment was conducted in two 0.4-ha orchards planted in 1981 with identical arrangements of 29 'Delicious' strains on M.7 and MM.111 rootstocks and with 'Idared' as the pollenizer. The orchards were originally designed to compare growth and productivity of the 'Delicious' strains and two rootstocks (Ketchie, 1987; Warrington et al., 1990), but the original arrangement of strains and rootstocks was ignored for the current experiment. Trees were spaced $3.7 \mathrm{~m} \times 5.5 \mathrm{~m}$. The orchards had a well-established sod cover except for a $1.5 \mathrm{~m}$ strip between rows maintained free of sod by herbicides according to commercial recommendations.

The soil in the orchards was a Warden fine sandy loam (coarse, silty, mixed, mesic, Xerollic Camborthids) that was uniform down the profile and overlaid fractured basalt bedrock. The permanent wilting percent and field capacity were $8 \%\left(80 \mathrm{~mm} \cdot \mathrm{m}^{-1}\right)$ and $28 \%\left(280 \mathrm{~mm} \cdot \mathrm{m}^{-1}\right)$ by volume, respectively, so that total available soil water was $200 \mathrm{~mm} \cdot \mathrm{m}^{-1}$. Soil depth varied for the two orchards. The orchard with shallow soil had an average depth of $0.8 \mathrm{~m}$ and $160 \mathrm{~mm}$ of total water available at field capacity (FC). The orchard with deeper soil had an average depth of $1.2 \mathrm{~m}$ and $240 \mathrm{~mm}$ of total water available at FC.

Irrigation treatments. The orchards were arranged in six rows with 31 trees per row. The orchards were overtree-sprinkler irrigated with 30 sprinkler heads. The sprinkler heads were divided into 10 sets of three sprinkler heads in each set. The sets were perpendicular to the long axis of the orchard and adjacent sets were three trees apart. The three sprinkler heads in 
each set were located in rows two, four, and six. The long axis of the orchards were oriented north to south.

In 1986, the first two sets of sprinkler heads at the north end of each orchard were shut off for the season before the first irrigation on 1 June. Before the second irrigation on 15 June, the next set (set three) was shut off. Before the third irrigation on 29 June, set four was shut off. The cycle was repeated biweekly with the next set of sprinkler heads shut off before irrigating. About $70 \mathrm{~mm}$ of water was applied at each irrigation. The quantity of water applied was measured by catch cans near each sprinkler head riser in row two. Thus, nine irrigation treatments with from 0 to $600 \mathrm{~mm}$ of water applied established a drought gradient the length of both orchards with the north end receiving no irrigation all season and the south end irrigated to within 3 weeks of harvest.

Soilmoisture measurementand evapotranspiration. Soil moisture was measured before and after each irrigation with a neutron probe via PVC access tubes located between every other tree in row two. Soil moisture was measured from 11 July 1986 through harvest.

Plant and fruit measurements. The trees were grouped into four categories: spur type on M.7, spur type on MM.111, nonspur type on M.7, and nonspur type on MM.111. One tree of each category (replication) was chosen per irrigation treatment in each orchard for data collection.

Stem water potential $\left(\Psi_{\text {stem }}\right)$ was measured on three leaves per tree with a pressure chamber after the method of Garnier and Berger (1985). Leaf vapor conductance was measured on five leaves per tree with a steady state porometer (LI-COR 1600, LI-COR, Lincoln, Nebr.). $\Psi_{\text {stem }}$ and leaf conductance were measured monthly starting in July, between 1300 HR and 1600 HR and on sunlit leaves that were perpendicular to the sun and near the base of current season's growth.

The lengths of ten terminal shoots per tree were measured after terminal buds set. Canopy density was determined on 15 July and 8 Sept. by visually rating trees for the percent of the canopy still retained on the trees compared to the controls. Trees were rated with $0 \%$ (no canopy), $25 \%, 50 \%, 75 \%$, or $100 \%$ (full canopy).

Full bloom was 20 Apr. 1986. Fruit weight of ten fruit per tree was determined monthly starting mid-June to harvest.

A Crop Water Deficit Index (CWDI) was determined using $\Psi_{\text {stem }}$ measurements and a modification of the procedure of Hiler and Clark (1971). The index was determined by finding the average absolute value of $\Psi_{\text {stem }}$ of each pair of consecutive measurements and multiplying by the number of days between the measurements. Index values for all consecutive $\Psi_{\text {stem }}$ measurements were summed to determine the total CWDI. The CWDI was determined from mid-July through harvest and compared to final fruit weight.

Carry-over-effect in 1987. In 1987, all trees were irrigated biweekly to maintain soil moisture near FC. Soil moisture was measured as described previously. Fruit weight was measured on 10 fruit per tree on 20 Sept.
Statistical analysis. Data were analyzed using the GLM, REG and NLIN procedures of the Statistical Analysis System (SAS Institute, Cary, N.C.). Specific analyses are indicated where appropriate.

\section{Results and Discussion}

Total available soil water (TAW). The orchards relied on winter precipitation and irrigation for most of the growing season because precipitation was low. Total precipitation was only $73 \mathrm{~mm}$ from May through September with most occurring the first week of May $(32 \mathrm{~mm})$ and after harvest in September (27 mm). Total pan evaporation was $1005 \mathrm{~mm}$ from May through September. Sequential termination of irrigation on progressive irrigation dates starting at the north end created a drought gradient the length of both orchards (Fig. 1). Soil mois- ture declined after the last irrigation for each treatment and was eventually nearly exhausted for the driest treatments. Control trees (trees last irrigated 7 Sept.) received $600 \mathrm{~mm}$ of water and TAW did not decline below $70 \%$.

The orchard planted on deeper soil depleted soil moisture more slowly than the orchard on shallow soil for each respective irrigation treatment. For example, the nonirrigated trees exhausted soil moisture in mid July in the orchard on shallow soil and in early September in the orchard on deep soil. The difference in rate of soil moisture depletion was due to the greater volume of stored water available for the orchard on deeper soil, since average canopy volume and evaporative demand were likely similar for both orchards, which were in close proximity. Water throughout the entire soil profile was utilized as indicated by similar soil moisture decline near

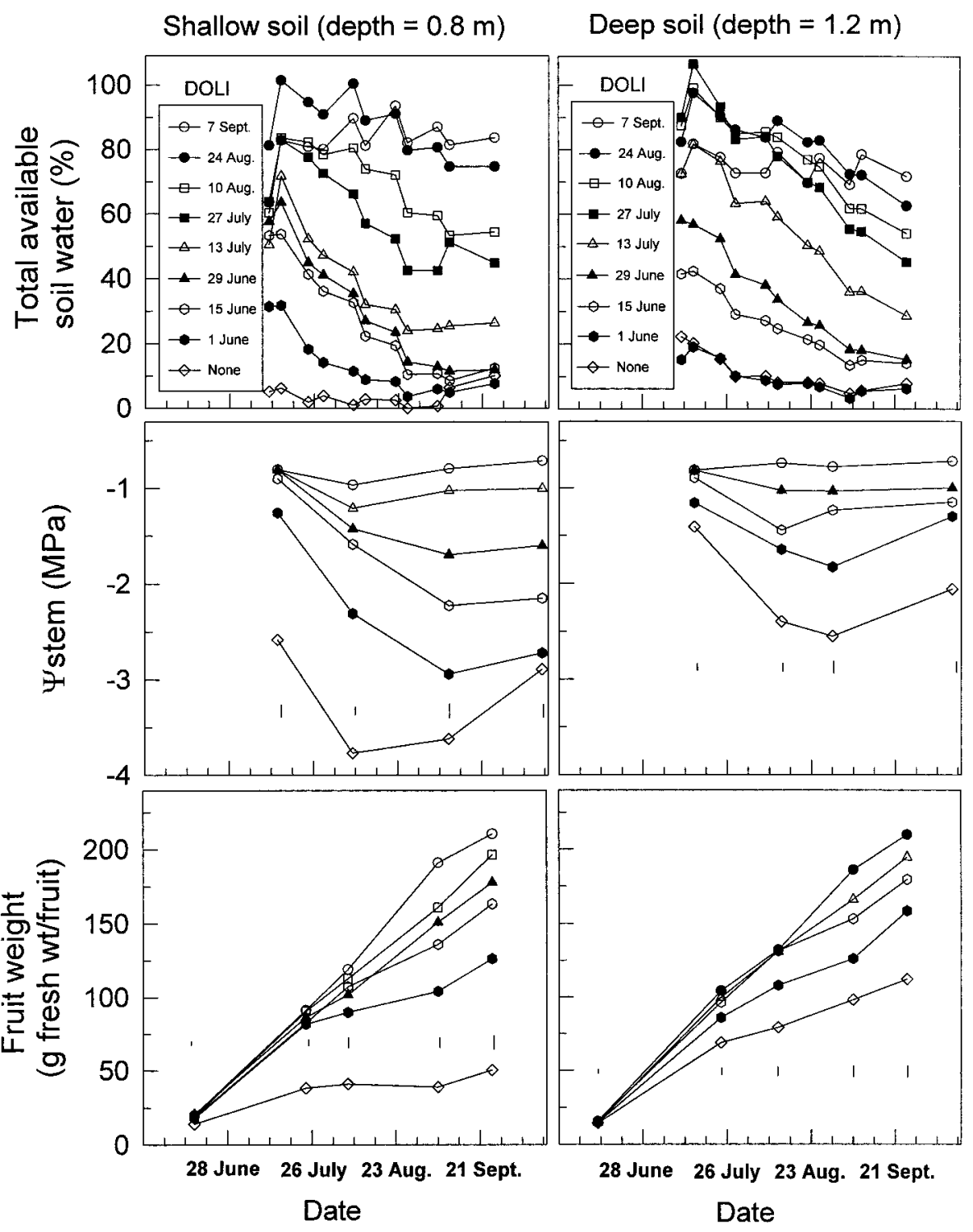

Fig. 1. Decrease in soil moisture, stem water potential $\left(\Psi_{\text {stem }}\right)$, and fruit weight after irrigation was terminated (date of last irrigation = 'DOLI') in two 'Delicious' apple orchards with different soil depths. Data points of irrigation treatments not shown were between adjacent treatments. Each data point for total available soil water represents the pooled mean across the soil profile of one neutron probe access tube per treatment. Each data point for stem water potential and fruit growth represent pooled means of four trees within the wetted pattern of each irrigation treatment. The vertical bars for stem water potential and fruit growth represent pooled SE of the means for each date. 
bedrock as at shallower depths (Fig. 2).

Plant water deficits. In the event of a water shortage that would result in early termination of irrigation, growers should measure soil moisture in the root zone, plant water status, and fruit size in order to best predict harvest potential of the crop. Soil moisture in the root zone should be measured to determine the total amount of water available to the orchard, and then canopy area and forecasted evaporative demand can be used to predict depletion rate of the stored water. However, soil moisture varies with depth and distance from tree roots and cover crop and therefore is not a reliable measure of drought stress of the tree.

A measure of plant water status would provide a more accurate measure of the actual progression of tree drought stress. The pressure bomb is a relatively inexpensive and simple device to operate and thus would be an excellent tool for commercial growers. Leaf water potential has been the most extensively studied for relating drought stress to plant water status, however, we (unpublished data) and others (Garnier and Berger, 1985) have found that there is less leaf to leaf variation in $\Psi_{\text {stem }}$ than leaf water potential measurements, and therefore $\Psi_{\text {stem }}$ would give more stable and reliable measurements.

$\Psi_{\text {stem }}$ changes diurnally, reaching a minimum in mid afternoon and a maximum just before dawn. Predawn measurements of plant water potential estimate average soil water potential across the root surface (Slatyer, 1967). Whereas these measurements are useful, especially since the majority of plant growth occurs at night when water-potential gradients are favorable for water movement into expanding cells, they would not provide much more information than a direct measure of soil moisture. Predawn plant water potential measurements ignore the impact that evaporative demand has on altering tree physiology during the day when stomates are open. The minimum $\Psi_{\text {stem }}$ that is reached during midday characterizes the maximum diurnal plant water deficits by incorporating the maximum evaporative demand of the day as well as soil moisture, which was the reason $\Psi_{\text {stem }}$ was measured at midday in this study.

$\Psi_{\text {stem }}$ decreased after the last irrigation for each irrigation treatment in concert with declining soil moisture (Fig. 1). $\Psi_{\text {stem }}$ reached their lowest values in August, the period of greatest seasonal plant water deficits, characterized by high evaporative demand and low TAW. $\Psi_{\text {stem }}$ increased somewhat in September due to cooler temperatures that reduced evaporative demand. Like TAW, $\Psi_{\text {stem }}$ of respective irrigation treatments was lower for trees in shallow soil than in deep soil. Leaf conductance in late August was only $12 \%$ and $17 \%$ of the control trees for nonirrigated trees in the shallow and deep soils, respectively, indicating extreme drought stress (data not shown).

In addition to measuring plant water status and soil moisture during a drought, decisions by industry personnel would be facilitated by a basic understanding of their relationships. An initial statistical analysis revealed no differences among dates or orchards (soil depth) for

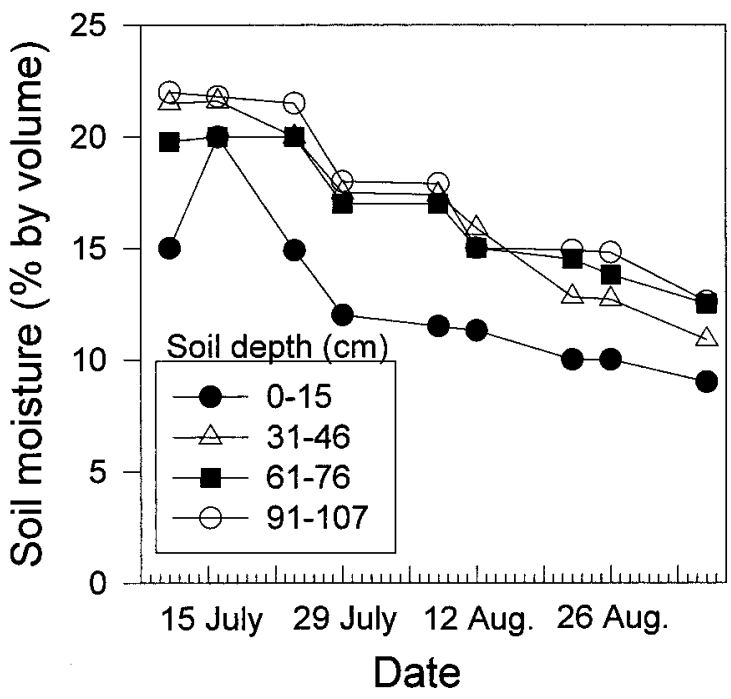

Fig. 2. Decrease in soil moisture at different depths after irrigation was terminated. The data shown are from a single neutron probe access tube for trees last irrigated 13 July 1986 in the orchard with soil 1.2-m deep. Data from all neutron probe access tubes demonstrated similarly that soil moisture was extracted from the surface down to bedrock.
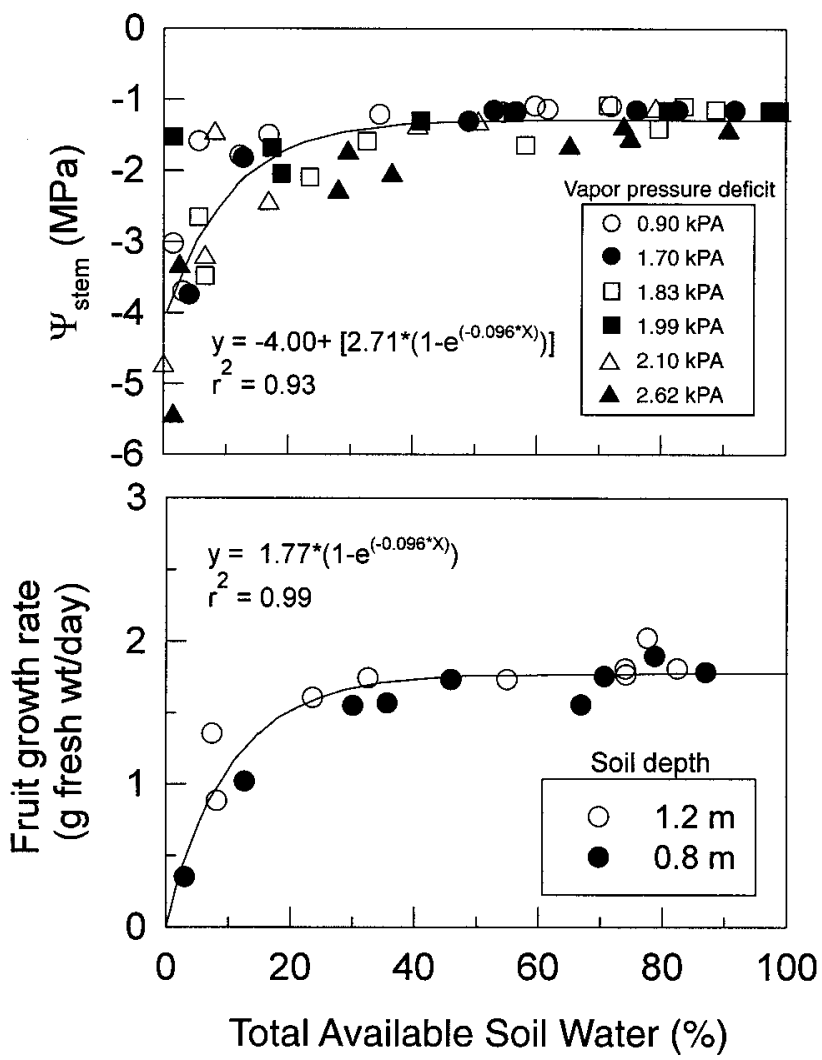

Fig. 3. Relationship of $\Psi_{\text {stem }}$ and fruit growth rate the last six weeks before harvest to total available soil water (TAW). The average vapor pressure deficit during $\Psi_{\text {stem }}$ measurements is shown. Each data point is a mean of four trees.

$\Psi_{\text {stem }}$ and TAW, therefore, a single nonlinear regression was derived (Fig. 3). The nonlinear relationship between measures of plant water potential and soil moisture have been determined before (Matthews et al., 1984). In Washington state, commercial growers are advised to irrigate when TAW declines to 35\% (James et al., 1989). In this study, $\Psi_{\text {stem }}$ was $93 \%$ and leaf conductance was $81 \%$ of the controls at $35 \%$ TAW, indicating that the trees are exposed to mild drought stress before irrigating even dur- ing nondrought years. In the event of a drought during which growers cannot irrigate at $35 \%$ TAW, TAW would continue to decline decreasing $\Psi_{\text {stem }}$ and stomatal aperture.

Vegetative growth. Defoliation varied across the orchard but there were clear delineations in the type and extent of defoliation based on phenological stage of shoot development. In June, when the trees were actively growing, the nonirrigated trees in the orchard on shallow soil rapidly shed nearly all leaves within a two- to 
three-week period (data not shown). Leaves emerged on these trees later in the season but were small, flat and pale green. Trees of the other treatments did not shed leaves more quickly than natural leaf shedding as exhibited by the controls until TAW and $\Psi_{\text {stem }}$ declined to $\approx 30 \%$ TAW and $-1.5 \mathrm{MPa}$, which did not start until July as shoot growth was slowing for the controls. Few leaves were shed at first with the number slowly increasing as drought stress intensified. Leaves senesced and abscised acropetally, with the transition leaves near the bud-scale scar the first leaves to turn yellow. By early September, leaf shedding reduced canopy density by $60 \%$ and $30 \%$ for nonirrigated trees in the shallow and deep orchards, respectively, and 35\% for trees last irrigated 1 June in the shallow orchard. Canopy density was not significantly affected in the other treatments.

Lengths of current season's shoots were reduced by $50 \%$ for nonirrigated trees on shallow soil, and $16 \%$ for nonirrigated trees on deep soil and trees irrigated once on 1 June on shallow soil. TAW and $\Psi_{\text {stem }}$ were first measured shortly before terminal buds set. At that time, trees that had a slight growth reduction had average $\Psi_{\text {stem }}$ of $-1.4 \mathrm{MPa}$. Since evaporative demand was lower and TAW higher before mid July, $\Psi_{\text {stem }}$ was probably not lower than -1.4 MPa for these treatments. It appears that shoot growth was reduced at $\Psi_{\text {stem }}$ slightly above $-1.4 \mathrm{MPa}$.

Crop load and fruit growth. June drop of apples was inhibited in the nonirrigated trees in both orchards, and trees last irrigated 1 June in the shallow orchard compared to wetter treatments.

Fruit weight was similar across irrigation treatments in mid-June, but thereafter growth slowed in the drier treatments and nearly stopped in the nonirrigated trees in the shallow orchard (Fig. 1). Like $\Psi_{\text {stem }}$, fruit growth rate from July through harvest was nonlinearly related to TAW (Fig. 3). Fruit growth rate at 35\% TAW, the minimum TAW that commercial growers are advised to irrigate, was $97 \%$ of the controls. Although some reduction in fruit size may occur as TAW declines to $35 \%$, fruit growth rate can temporarily accelerate when soil moisture is replenished such that fruit size is not reduced at harvest compared to well watered controls (Ebel et al., 1995). Although the relationship of TAW to fruit growth rate is informative of the progress of drought stress at any given moment in time, a model that incorporates drought stress over time would be more useful in predicting fruit weight at harvest. Mathematical models have been developed to predict soil moisture depletion of apple orchards (Best et al., 1987; Buchleiter et al., 1988; Mannocchi and Mecarelli, 1995). Additional models that incorporate plant water status and fruit growth would provide a predictive system that would give commercial growers advance warning of the harvest potential of their crop. The close relationship of fruit growth and $\Psi_{\text {stem }}$ to TAW indicates that a model could be developed to predict fruit weight at harvest. Naor et al. (1995) also recommended using $\Psi_{\text {stem }}$ as the preferred plant water-stress indicator for apple

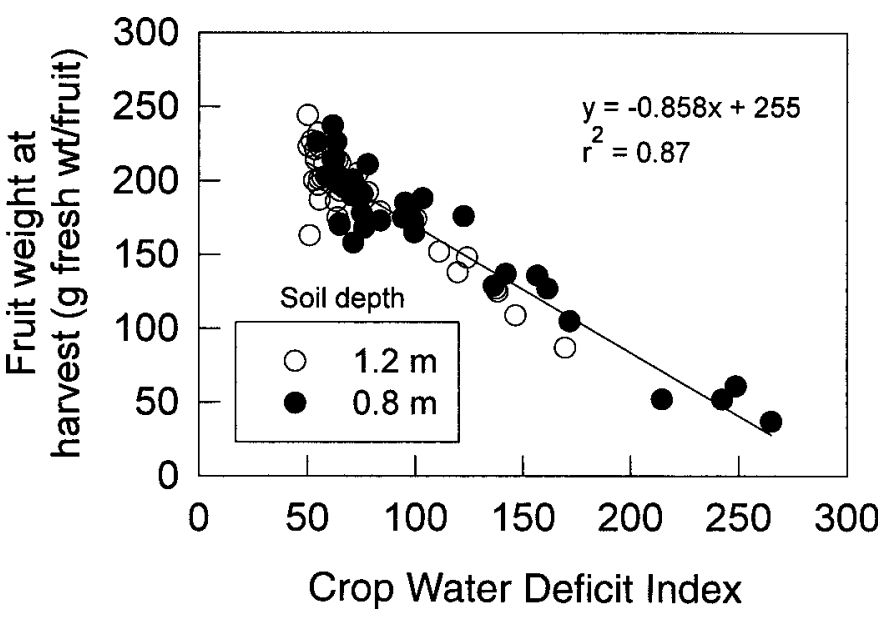

Fig. 4. Regression of the crop water deficit index (CWDI) to fruit weight at harvest. The regression was significant at $P=0.05$. Each data point represent individual trees.

Table 1. Analysis of variance (ANOVA) to determine differences in drought response of 'Delicious' growth habits (spur versus nonspur type) and two rootstocks. Drought stress was imposed by terminating irrigation for the rest of the season on different dates for different treatments (DOLI = date of last irrigation). The treatments were imposed in two orchards. The analysis was conducted with DOLI as a fixed variable and conducted as a complete block design with orchard put into the model as the block. Trunk cross-sectional area (TCA) are shown to illustrate the inherent differences in tree size before drought was imposed. Midday stem water potential $\left(\Psi_{\text {stem }}\right)$ and leaf-conductance measurements were made in August, the period during the growing season exhibiting the greatest plant water deficits characterized high evaporative demand and low soil moisture. Fruit weight was measured at harvest.

\begin{tabular}{|c|c|c|c|c|}
\hline & $\begin{array}{l}\mathrm{TCA} \\
\left(\mathrm{cm}^{2}\right) \\
\end{array}$ & $\begin{array}{l}\Psi_{\text {stem }} \\
(\mathrm{MPa})\end{array}$ & $\begin{array}{c}\text { Leaf conductance } \\
\left(\mathrm{mmol} \cdot \mathrm{m}^{-2} \cdot \mathrm{s}^{-1}\right)\end{array}$ & $\begin{array}{c}\text { Fruit fresh } \\
\text { wt }(\mathrm{g}) \\
\end{array}$ \\
\hline \multicolumn{5}{|c|}{ Significance } \\
\hline DOLI & $--^{z}$ & $*$ & $*$ & $*$ \\
\hline Growth Habit (G) & $*$ & $*$ & $*$ & $*$ \\
\hline Rootstock (R) & NS & NS & NS & NS \\
\hline $\mathrm{G}^{*} \mathrm{R}$ & NS & NS & NS & NS \\
\hline DOLI*G & --- & NS & NS & NS \\
\hline DOLI* ${ }^{*} \mathrm{R}$ & --- & NS & NS & NS \\
\hline DOLI*G*R & --- & NS & NS & NS \\
\hline \multicolumn{5}{|c|}{ Means } \\
\hline Growth Habit & & & & \\
\hline Spur type & 44 & $-1.35 \mathrm{a}$ & $170 \mathrm{a}$ & $187 \mathrm{a}$ \\
\hline Nonspur type & 58 & $-1.48 \mathrm{~b}$ & $150 \mathrm{~b}$ & $177 \mathrm{~b}$ \\
\hline \multicolumn{5}{|c|}{ Rootstock } \\
\hline M.7 & 46 & -1.41 & 158 & 179 \\
\hline MM.111 & 56 & -1.42 & 161 & 185 \\
\hline
\end{tabular}

size. The CWDI index has been shown to be an accurate predictor of yield for other crops (Hiler and Clark, 1971). In the current study, a significant relationship $\left(r^{2}=0.87^{*}\right)$ was found between CWDI and fruit weight at harvest (Fig. 4). This relationship was statistically significant despite the inherent variation in scions and rootstocks within the experiment, and was independent of soil depth.

Differences among growth habits and rootstocks. The high plant water deficits in August would have most likely accentuated differences in leaf conductance and $\Psi_{\text {stem }}$ between growth habits and rootstocks, especially considering the large, inherent differences in canopy volume (Ketchie, 1987; Warrington et al., 1990). The nonspur trees exhibited greater drought stress as indicated by lower $\Psi_{\text {stem }}$, leaf conductance, and fruit weight (Table 1). The largest trees were nonspur types on MM.111 rootstock (average TCA = $63 \mathrm{~cm}^{2}$ ) and the smallest spur types on M.7 rootstock (average TCA $=40 \mathrm{~cm}^{2}$ ). Roots of the larger trees are capable of penetrating up to 3 to $4 \mathrm{~m}$ in soil, however, this soil was only 0.8 to $1.2-\mathrm{m}$ deep due to bedrock. It is likely that the greater drought stress symptoms of the larger trees compared to the smaller trees was due to faster depletion of soil moisture in the root zone, although soil moisture was not measured directly under each tree. There were no differences in $\Psi_{\text {stem }}$, leaf conductance or fruit weight between the two rootstocks.

The literature is not clear on differences in water relations and fruit growth among apple cultivars and rootstocks under drought conditions. Most studies report that apple cultivars and rootstocks vary in their response to drought 


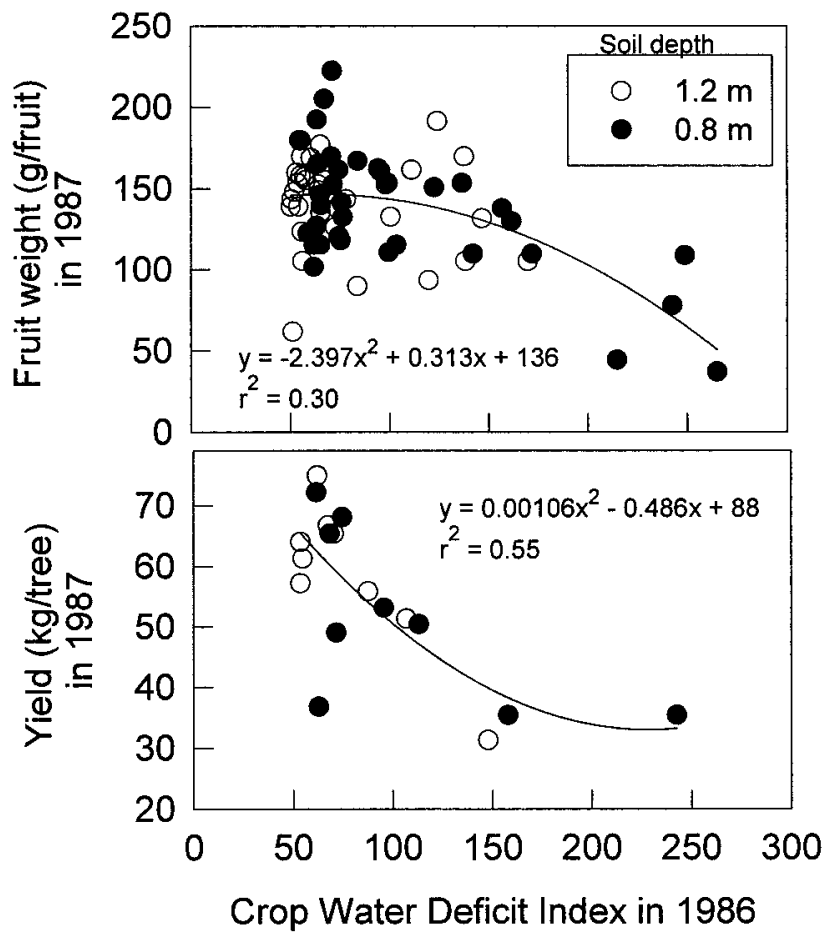

Fig. 5. Regressions of the crop water deficit index (CWDI) in 1986 on fruit weight and yield in 1987. The trees were irrigated normally in 1987. Each data point for fruit weight is of a single tree. Each data point for yield is the mean of four trees within the wetted pattern of each irrigation treatment of 1986. Both regressions were significant at $P=0.05$.

stress (Atkinson et al., 1998; Atkinson et al., 1997; Fernandez et al., 1997; Giulivo et al., 1985, Olien and Lakso, 1986). Models developed to predict fruit weight at harvest during a drought may have to be made for specific cultivar/rootstock combinations.

Carry-over-effect in 1987. There was no dieback of shoots in 1987 and all trees survived. Fruit weight and yield at harvest in 1987 was slightly affected by drought in 1986 with the greatest effect for trees nonirrigated or trees in shallow soil and irrigated once on 1 June 1986 (Fig. 5).

\section{Literature Cited}

Assaf, R., I. Levin, and B. Bravdo. 1975. Effect of irrigation regimes on trunk and fruit growth rates, quality and yield of apple trees. J. Hort. Sci. 50:481-493.

Atkinson, C.J., M. Policarpo, A.D. Policarpo, A.D Webster, and A.M. Kuden. 1998. Drought tolerance of apple rootstocks: Production and partitioning of dry matter. Plant \& Soil 206:223-235.

Atkinson, C.J., A.D. Webster, M. Policarpo, and A. Kuden. 1997. Drought sensitivity of apple rootstocks. Acta Hort. 451:171-178.

Best, K.R. 1987. Washington irrigation forecast: An interactive computerized irrigation scheduling program. M.S. Thesis, Washington State Univ., Pullman.

Buchleiter, G.W., H.R. Duke, and D.F. Heermann. 1988. User's guide for USDA-ARS irrigation scheduling program SCHED. USDA-Agr. Res. Serv. Agr. Eng. Res. Ctr., Colorado State Univ., Fort Collins.

Chalmers, D.J., G. Burge,P.H. Jerie, and P.D. Mitchell. 1986. The mechanism of 'Bartlett' pear fruit and vegetative growth by irrigation withholding and regulated deficit irrigation. J. Amer. Soc. Hort. Sci. 111:904-907.
Chalmers, D J., P.D. Mitchell, and L. van Heek. 1981. Control of peach tree growth and productivity by regulated water supply, tree density, and summer pruning. J. Amer. Soc. Hort. Sci. 106:307-312.

Davies, F.S. and A.N. Lakso. 1979. Diurnal and seasonal changes in leaf water potential components and elastic properties in response to water stress in apple trees. Physiologia Plantarum 46:109-114.

Ebel,R.C.,E.L. Proebsting, and M.EPatterson. 1993. Regulated deficit irrigation may alter apple maturity, quality and storage life. HortScience 28:141143.

Ebel, R.C., E.L. Proebsting, and R.G. Evans. 1995. Deficit irrigation to control vegetative growth in apple and monitoring fruit growth to schedule irrigation. HortScience 30:1229-1232.

Fernandez, R.T., R.L. Perry, and J.A. Flore. 1997. Drought response of young apple trees on three rootstocks. II. Gas exchange, chlorophyll fluorescence, water relations, and leaf abscisic acid. J. Amer. Soc. Hort. Sci. 122:14-19.

Ferree, D.C. and J.C. Schmid. 1990. Performance of apple rootstock, cultivars and cultural treatments under the stress of the 1988 drought. Res. Circular-Ohio Agr. Res. Dev. Center 297:25-36.

Garnier, E. and A. Berger. 1985. Testing water potential in peach trees as an indicator of water stress. J. Hort. Sci. 60:47-56

Giulivo, C., G. Ponchia, A. Gianola, and A. Pitacco. 1985. Effect of rootstock-scion combination on water balance of apple tree, cv Golden Delicious. Acta Hort. 171:399-404.

Heermann, D. F., H.R. Duke, and G.W. Buchleiter. 1985. 'User friendly' software for an integrated water-energy management system for center pivot irrigation. Computers \& Electronics in Agr. 1:4157.

Higgs, K.H. and H.G. Jones. 1991. Water relations and cropping of apple cultivars on a dwarfing rootstock in response to imposed drought. J. Hort. Sci. 66:367-379.

Hiler, E.A. and R.N. Clark. 1971. Stress day index to characterize effects of water stress on crop yields. Trans. Amer. Soc. Agric. Eng. 14:757-761.

James, L.G., J.M. Erpendbeck, D.L. Bassett, and J.E. Middleton. 1989. Irrigation requirements for Washington-Estimates and methodology. Wash. State Univ. Coop. Ext., Bul. 1513.

Jones, H.G., A.N. Lakso and J.P. Syversten. 1985 Physiological control of water status in temperate and subtropical fruit trees. Hort. Rev. 7:301-344.

Ketchie, D.O. 1987. Delicious strain evaluation summary given at hort meet. The Goodfruit Grower $38(2): 8-11$.

Kleingartner,L.G. 1977. Data on weather from 19241976. Wash. State Univ. Coop. Ext. Bul. 858.

Landsberg, J.J. and H.G. Jones. 1981. Apple orchards, p. 419-469. In: T.T. Kozlowsi (ed.). Water deficits and plant growth. Vol. VI. Woody plant communities. Academic Press, London.

Li, S.H., J.G. Huguet, P.G. Schoch, and P. Orlando. 1989. Response of peach tree growth and cropping to soil water deficit at various physiological stages of fruit development. J. Hort. Sci. 64:541552.

Ludlow, M.M., K.J. Sommer, D.J.Flower, R. Ferraris, and H.B. So. 1989. Influence of root signals resulting from soil dehydration and high soil strength on the growth of crop plants. Current Topics Plant Biochem. Physiol. 8:81-99.

Mannocchi, F. and P. Mecarelli. 1995. A soil-watercrop model for large and small scale applications, p. 105-120. In: L.S. Pereira, B.J. van den Broek, P. Kabat, and R.G. Allen (eds.) Crop-watersimulation models in practice: Selected papers of the $2^{\text {nd }}$ Workshop, $15^{\text {th }}$ Cong. of the Intl. Commission on Irr. and Drainage. Waheningen Pers, Wageningen, Netherlands.

Matthews, M.A., E. Volkenburgh, and J.S. Boyer. 1984. Acclimation of leaf growth to low water potentials in sunflower. Plant, Cell Env. 7:199206

Mills, T.M., B.E. Clothier, and M.H. Behboudian. 1997. The water relations of 'Braeburn' apple fruit grown under deficit irrigation. Acta Hort. 449:385-392.

Mitchell, P.D. and D.J. Chalmers. 1982. The effect of reduced water supply on peach tree growth and yields. J. Amer. Soc. Hort. Sci. 197:853-856.

Mitchell, P.D., D.J. Chalmers, P.H. Jerie, and G. Brge. 1986. The use of initial withholding of irrigation and tree spacing to enhance the effect of regulated deficit irrigation on pear trees. J. Amer. Soc. Hort. Sci. 111:858-861.

Mitchell, P.D., P.H. Jerie, and D.J. Chalmers. 1984. The effects of regulated water deficits on pear tree growth, flowering, fruit growth, and yield. J. Amer. Soc. Hort. Sci. 109:604-606.

Naor, A., I Klein, and I. Doron. 1995. Stem water potential and apple size. J. Amer. Soc. Hort. Sci. 120:577-582.

Olien, W.C. and A.N. Lakso. 1986. Effect of rootstock on apple (Malus domestica) tree water relations. Physiol. Plant. 67:421-430.

Powell, D.B.B. 1976. Some effects of water stress on the growth and development of apple trees. J. Hort. Sci. 51:75-90.

Proebsting, E.L. and J.E. Middleton. 1980. The behavior of peach and pear trees under extreme drought stress. J. Amer. Soc. Hort. Sci. 105:380385 .

Proebsting, E.L., J.E. Middleton, and M.O. Mahan. 1981. Performance of bearing cherry and prune trees under very low irrigation rates. J. Amer. Soc. Hort. Sci. 106:243-246.

Slatyer, R.O. 1967. Plant-water relationships. Academic Press, New York.

Warrington, I.J., D.C. Ferree, J.R. Schupp, F.G. Dennis, Jr., and T.A. Baugher. 1990. Strain and rootstock effects on spur characteristics and yield of 'Delicious' apple strains. J. Amer. Soc. Hort. Sci. 115:348-356 